\title{
PERBAIKAN PROSES DAN HASIL BELAJAR MUATAN IPA TEMA 4 MENGGUNAKAN MODEL PEMBELAJARAN DISCOVERY LEARNING (DL) SISWA KELAS 5 SD NEGERI DUKUH 01 KECAMATAN SIDOMUKTI KOTA SALATIGA TAHUN 2017/2018
}

\author{
Rizki Sofyan Rizal1, Nyoto Harjono2, Gamaliel Septian Airlanda ${ }^{3}$ \\ ${ }^{1}$ Pendidikan Guru Sekolah Dasar, Universitas Kristen Satya Wacana, 292014058@student.uksw.edu \\ ${ }^{2}$ Pendidikan Guru Sekolah Dasar, Universitas Kristen Satya Wacana, har.john59@gmail.com \\ ${ }^{3}$ Pendidikan Guru Sekolah Dasar, Universitas Kristen Satya Wacana, gama.airlanda@staff.uksw.edu
}

\section{INFO ARTIKEL \\ Riwayat Artikel: \\ Diterima: 21-03-2018 \\ Disetujui: 05-04-2018}

\section{Kata Kunci:}

Proses

Hasil Belajar

Discovery Learning

\section{ABSTRAK}

\begin{abstract}
Abstrak: Penelitian ini merupakan penelitian tindakan kelas (PTK). Hasil penelitian adalah bahwa penerapan model $D L$ dapat memperbaiki proses dan hasil belajar muatan ipa tema 4 . Pada siklus I, persentase ketercapaian aktivitas guru sebesar $86 \%$ yang kemudian meningkat pada siklus II menjadi 98\% dan ketercapaian aktivitas siswa pada siklus I sebesar $81,3 \%$ yang kemudian meningkat pada siklus II menjadi 94\%. Peningkatan hasil belajar muatan IPA dilihat dari aspek kognitif persentase ketuntasan untuk siklus I mencapai $73,5 \%$ dan meningkat pada siklus II menjadi $100 \%$.
\end{abstract}

\section{A. LATAR BELAKANG}

Pendidikan merupakan sesuatu yang dinamis karena pendidikan menuntut adanya suatu perbaikan yang dilakukan secara terus menerus seiring dengan perkembangan zaman. Salah satu yang dilakukan adalah perbaikan kurikulum pendidikan yang bertujuan untuk meningkatkan mutu pendidikan di Indonesia, seperti kurikulum 2006 yang hanya menekankan pada aspek kognitif saja dan dilakukan pergantian kurikulum untuk meningkatkan mutu pendidikan yaitu kurikulum 2013 yang tidak hanya menekankan pada aspek kognitif saja namun aspek afektif dan aspek psikomotor juga ditekankan. Penerapan Kurikulum 2013 disajikan dalam model pembelajaran tematik integratif. Kurikulum 2013 mempunyai tujuan untuk mempersiapkan insan Indonesia yang memiliki kemampuan hidup sebagai pribadi dan warga negara yang produktif, kreatif, inovatif, dan efektif, serta mampu berkontribusi pada kehidupan bermasyarakat, berbangsa, bernegara dan peradaban dunia (Permendikbud Nomor 66 Tahun 2013). Sedangkan aspek utama pada Kurikulum 2013 yaitu Standar Kompetensi Lulusan (SKL), Kompetensi inti (KI), Kompetensi Dasar (KD), dan indikator yang berbasis scientific approach dan authentic assessment. Kurikulum 2013 memilikii karakteristik yaitu lebih menekankan pada pencapaian sikap, pengetahuan, dan keterampilan. Kemendikbud (2013) menyatakan bahwa pembelajaran tematik integratif merupakan pendekatan pembelajaran yang mengintegrasikan berbagai kompetensi dari berbagai mata pelajaran ke dalam berbagai tema. Pembelajaran tematik-terpadu merupakan pendekatan pembelajaran yang memadukan berbagai kompetensi dari berbagai mata pelajaran ke dalam berbagai tema (Madjid, 2014). Penilaian dalam pembelajaran tematik integratif dilakukan dengan asesmen autentik, yaitu asesmen yang melibatkan siswa di dalam tugas-tugas autentik yang bermanfaat, penting, dan bermakna. (Hosnan, 2014) Pembelajaran tematik integratif diharapkan mampu melahirkan peserta didik yang kreatif, cerdas dan inovatif.

Kenyataannya hasil pengamatan pada kegiatan pembelajaran muatan IPA tema 4 siswa kelas 5 SD Negeri Dukuh o1 Kecamatan Sidomukti Kota Salatiga tahun pelajaran 2017/2018 ditemukan masalah dalam proses pembelajarannya yaitu siswa kurang antusias dalam bertanya dan menjawab. Aktivitas belajar yang belum optimal dapat berdampak pada nilai muatan IPA 
tema 4 masih kurang maksimal, hal ini terlihat dari 34 siswa yang mengikuti ulangan harian, ada sekitar 19 siswa harus mengikuti program perbaikan atau remedial karena nilainya di bawah KKM yang ditentukan yaitu 7,00. Hal ini diperkuat dengan hasil wawancara guru kelas 5 yang mengungkapkan bahwa siswa kelas 5 kurang antusias dalam bertanya saat guru meminta siswa untuk bertanya dan yang belum paham tentang materi yang sudah dijelaskan oleh guru. Siswa juga kurang antusias dalam menjawab pertanyaan dari guru dan adanya rasa takut salah dikarenakan siswa tidak tahu apa yang mau ditanyakan dan tidak tahu apa jawaban dari pertanyaan dari guru. Kurang maksimalnya hasil belajar dikarenakan siswa kurang aktif di dalam kelas sehingga siswa sulit untuk memahami pembelajaran IPA. Dari data yang diperoleh maka dibutuhkan model pembelajaran yang dapat menjadikan siswa menjadi aktif.

Pembelajaran yang menekankan pada pembelajaran siswa aktif dalam menemukan konsep sendiri diantaranya adalah metode discovery (Kemendikbud, 2013). Model discovery learning merupakan proses pembelajaran yang melibatkan siswa untuk mengorganisasikan sendiri materi pembelajaran dengan penekanan pada penemuan konsep atau prinsip yang sebelumnya tidak diketahui siswa, (Kemendikbud 2016: 60). Pembelajaran discovery (discovery learning) merupakan suatu model pembelajaran yang dikembangkan oleh J. Bruner berdasarkan pada pandangan kognitif tentang pembelajaran dan prinsipprinsip konstruktivis (Depdiknas,2005). Discovery learning adalah strategi pembelajaran yang cenderung meminta siswa untuk melakukan observasi, eksperimen, atau tindakan ilmiah hingga mendapatkan kesimpulan dari hasil tindakan ilmiah tersebut (Saifuddin, 2014). Menurut Bruner (Wicaksono, dkk, 2015: 190) "Discovery learning bermanfaat dalam; 1) peningkatan potensi intelektual siswa; 2) perpindahan dari pemberian reward ekstrinsik ke intrinsik; 3) pembelajaran menyeluruh melalui proses menemukan; 4) alat untuk melatih memori”. Discovery merupakan pembelajaran berdasarkan penemuan, konstruktivis dan teori bagaimana belajar. Model discovery learning ialah dimana peserta belajar untuk mengenali masalah, solusi, mencari informasi yang relevan, mengembangkan strategi solusi, dan melaksanakan strategi yang dipilih.

Menurut (Anitah, 2009) belajar penemuan atau Discovery Learning merupakan suatu pembelajaran yang melibatkan peserta didik dalam pemecahan masalah untuk pengembangan pengetahuan dan keterampilan. Melalui penemuan, peserta didik belajar secara intensif dengan mengikuti metode investigasi ilmiah di bawah supervisi guru. Jadi belajar dirancang, disupervisi, diikuti metode investigasi. Tiga ciri utama dari belajar menemukan (Discovery Learning) yaitu : (1) mengeksplorasi dan memecahkan masalah untuk menciptakan, menggabungkan dan menggeneralisasikan pengetahuan; (2) berpusat pada siswa (3) kegiatan untuk menggabungkan pengetahuan baru dan pengetahuan yang sudah ada. Model Discovery Learning dapat meningkatkan aktivitas dan prestasi belajar siswa. Melalui belajar penemuan, peserta didik belajar secara intensif dengan mengikuti metode investigasi ilmiah dan cenderung meminta siswa untuk melakukan observasi, eksperimen, atau tindakan ilmiah hingga mendapatkan kesimpulan dari hasil tindakan ilmiah.

Langkah pembelajaran model discovery learning yang digunakan dalam penelitian ini pertama adalah : (1) Stimulation (stimulasi/pemberian rangsangan). Pelajar dihadapkan pada sesuatu yang menimbulkan penasaran. (2) Problem statement (pernyataan/ identifikasi masalah) Guru memberi kesempatan kepada siswa untuk mengidentifikasi sebanyak mungkin agendaagenda masalah dirumuskan dalam bentuk hipotesis. (3) Data collection (pengumpulan data) Ketika eksplorasi berlangsung guru juga memberi kesempatan kepada para siswa untuk mengumpulkan informasi sebanyakbanyaknya yang relevan untuk membuktikan benar atau tidaknya hipotesis (4) Data processing (pengolahan data) Kegiatan mengolah data dan informasi yang telah diperoleh para siswa (5) Verification (pentahkikan/pembuktian). Bertujuan agar proses belajar akan berjalan dengan baik dan kreati (6) Generalization (menarik kesimpulan / generalisasi). Proses menarik sebuah kesimpulan yang dapat dijadikan prinsip umum dan berlaku untuk semua kejadian atau masalah yang sama, dengan memperhatikan hasil verifikasi.

Sementara itu suatu proses pembelajaran tentunya memiliki keinginanan untuk mencapai tujuan tertentu berupa hasil belajar.

Menurut Oemar Hamalik (2006:30), hasil belajar adalah bila seseorang telah belajar akan terjadi perubahan tingkah laku pada orang tersebut, misalnya dari tidak tahu menjadi tahu, dan dari tidak mengerti menjadi mengerti. Gagne (1985 dalam Uno 2010: 17) mengemukakan bahwa "hasil belajar merupakan pengalaman-pengalaman belajar yang diperoleh siswa dalam bentuk kemampuan-kemampuan tertentu”. Hasil belajar dibagi menjadi tiga macam yaitu: (a) keterampilan dan kebiasaan, (b) pengetahuan dan pengertian, (c) sikap dan cita-cita, yang masing-masing golongan dapat diisi dengan bahan yang ada pada kurikulum sekolah Sudjana dalam (Rumidani, Marhaeni, \& Tika, 2014).

Bloom menyatakan hasil belajar merupakan prestasi belajar peserta didik secara keseluruhan yang menjadi indikator kompetensi dan derajat perubahan perilaku. Menurut Bloom (2010), hasil belajar diklasifikasikan ke dalam tiga ranah, yaitu: 1) ranah kognitif (cognitive domain); 2) ranah afektif (affective domain); dan 3) ranah psikomotor (psychomotor domain). Hasil belajar dalam ranah kognitif terdiri enam kategori yaitu: pengetahuan, pemahaman, penerapan, analisi, sintesis 
dan evaluasi merupakan ranah kognitif tingkat tinggi. Ranah afektif berkenaan dengan sikap yang terdiri dari lima aspek, yaitu: menerima, menanggapi, menilai, mengelola, dan menghayati. Ranah psikologi berkenaan dengan hasil belajar keterampilan dan kemampuan bertindak yakni: menirukan, memanipulasi, pengalamiahan, dan artikulasi.

Bettencourt (Suparno, 2012: 61) yang menuliskan bahwa, "Hasil belajar dipengaruhi oleh pengalaman siswa dengan dunia fisik dan lingkungannya". Hasil belajar seseorang tergantung pada apa yang telah diketahuinya; misal konsep-konsep. Chatib (2012: 169170), "Hasil belajar tidak hanya terbatas pada tes atau ujian saja tetapi sangat luas. Hasil belajar dapat dilihat dari; a) perubahan perilaku anak; b) perubahan pola pikir anak; c) membangun konsep baru".

Berdasarkan pendapat para ahli, hasil belajar dalam penilitian ini mengikuti pendapat dari Bloom yang berpendapat bahwa hasil belajar diklasifikasikan kedalam tiga ranah, yaitu: 1) ranah kognitif 2) ranah afektif dan 3) ranah psikomotor. Tetapi hasil belajar pada penelitian ini hanya mengkhususkan pada ranah kognitif saja yaitu dengan cara siswa diberi soal tes atau ulangan harian setelah kegiatan belajar mengajar yang diberikan oleh guru selesai sehingga siswa mendapatkan nilai dan nilai yang di dapatkan dari siswa itu merupakan hasil belajar pada ranah kogitif. Cara mengukur hasil belajar dengan tes dan lembar observasi.

Tujuan penelitian yang ingin dicapai yaitu (1) Menerapkan model discovery learning untuk memperbaiki proses pembelajaran muatan IPA tema 4 siswa kelas 5 SD Negeri Dukuh 01 Kecamatan Sidomukti Kota Salatiga tahun 2017/2018. (2) Memperbaiki hasil belajar muatan IPA tema 4 siswa kelas 5 SD Negeri Dukuh 01 Kecamatan Sidomukti Kota Salatiga tahun 2017/2018 melalui peningkatan proses menggunakan model discovery learning.

\section{B. METODE PENELITIAN}

Jenis penelitian ini menggunakan kuantitatif dengan deskripsi statistik. Penelitian dilakukan di SD Negeri Dukuh o1 Salatiga yang terletak di kelurahan Dukuh, Kecamatan Sidomukti, Kota Salatiga.Letak sekolah di pinggir jalan yaitu samping perempatan lampu merah grogol sehingga dapat dijangkau dengan mudah baik dengan kendaraan pribadi maupun kendaraan umum seperti angkot. Penelitian dilakukan pada semester I, tahun ajaran 2017/2018 di SD Negeri Dukuh 01. Penelitian tindakan kelas siklus I dilaksanakan sebanyak 3 kali pertemuan, 2 kali tatap muka dan 1 ambil data yang dimulai pada Minggu pertama bulan November sampai akhir bulan November. Subjek penelitian ini adalah siswa kelas 5 SD Negeri Dukuh o1 tahun pelajaran 2017/2018. Siswa kelas 5 SD Negeri Dukuh 01 berjumlah 34 siswa terdiri dari 20 siswa laki-laki dan 14 siswa perempuan.
Penelitian ini dilakukan dalam dua siklus dengan tiap siklus dilaksanakan tiga kali pertemuan yang terdiri dari dua pertemuan tatap muka dan satu pertemuan evaluasi. Siklus I terdiri dari tiga tahap meliputi, tahap perencanaan tindakan, pelaksanan tindakan dan observasi, serta refleksi. Hasil refleksi pada siklus I digunakan untuk perbaikan pada pembelajaran siklus II. Tahapan pada siklus II meliputi, tahap perencanaan tindakan, tahap pelaksanaan tindakan dan observasi, serta refleksi. Apabila pembelajaran pada siklus II sudah memenuhi pencapaian untuk aktivitas belajar meningkat secara signifikan minimal 15\%, dan ketuntasan belajar secara klasikal dengan nilai rata-rata hasil belajar muatan IPA tema 4 meningkat minimal 10 skor dari nilai KKM $(\geq 70)$ yang telah ditentukan atau ketuntasan belajar klasikal sebesar $80 \%$ dari 34 siswa. Maka tidak perlu diadakan perbaikan kembali dan penerapan model pembelajaran discovery learning pada pembelajaran IPA dinyatakan berhasil.

Pada penelitian ini, peneliti menggunakan tes tertulis sebagai alat pengumpulan data hasil belajar siswa tema 4 muatan IPA, dalam mengamati proses pembelajaran peneliti menggunakan lembar observasi. Pada uji validitas, instrumen soal tes siklus 1 instrumen soal valid jika koefisien corrected item to total correlation > 0,349 dan pada siklus 2 instrumen soal valid jika koefisien corrected item to total correlation $>$ 0,329. Pada siklus 1 uji reliablilitas istrumen soal setelah dikurangi item yang tidak valid diuji tingkat reliabilitasnya dengan Cronbach's Alpha sebesar 0,714 dari 30 item yang diuji dan pada siklus 2 instrumen soal setelah dikurangi item yang tidak valid diuji tingkat reliabilitasnya dengan Cronbach's Alpha sebesar 0,651 dari 30 item yang diuji.

Data yang diperoleh dari hasil pelaksanaan penelitian tindakan kelas adalah data kuantitatif. Penelitian ini menggunakan analisis kuantitatif dengan statistik deskriptif. Sedangkan data hasil belajar muatan IPA dianalisis menggunakan teknik analisis deskriptif komparatif untuk membandingkan hasil belajar setelah tindakan siklus I dan siklus II.

\section{HASIL DAN PEMBAHASAN \\ 1. Deskripsi Pra Siklus}

Berdasarkan pengamatan terhadap proses belajar mengajar muatan IPA siswa kelas 5 SDN Dukuh 01 sebelum dilaksanakan tindakan menunjukan adanya permasalahan. Proses pembelajaran muatan IPA siswa pasif dan kurang antusias mengikuti pembelajaran. Terbukti dari hasil observasi aktivitas guru prasiklus, dari 20 indikator pengamatan memperoleh skor 34 dengan persentasae 34\% masuk dalam kategori kurang. Kemudian aktivitas siswa prasiklus memperoleh ratarata skor klasikal sebesar 20 dengan persentase $26,7 \%$ masuk dalam kategori kurang.

Ternyata aktivitas belajar yang belum optimal berdampak pada rendahnya hasil belajar. Hasil tes 
ulangan harian muatan IPA menunjukan nilai rata-rata klasikal 63,5 yang berarti belum mencapai KKM (70). Nilai tertinggi yang diperoleh siswa adalah 86 sedangkan nilai terendahnya 46. Kemudian ketuntasan belajar prasiklus sebanyak 21 siswa dinyatakan belum mencapai KKM atau $61,76 \%$ dari keseluruhan siswa, sedangkan yang dinyatakan tuntas sebanyak 13 siswa atau $38,24 \%$ dari keseluruhan siswa.

\section{Deskripsi Siklus I}

Pelaksanaan tindakan siklus I ini terdiri dari tiga pertemuan, yaitu pertemuan 1, 2 dan 3 yang berlangsung pada hari Selasa, Rabu dan Jumat tanggal 7, 8 dan 10 November 2017. Hal - hal yang dilakukan pada kegiatan Siklus I adalah Perencanaan antara lain :rencana pelaksanaan pembelajaran (RPP) siklus I, lembar observasi atau pengamatan aktivitas siswa dalam proses pembelajaran, lembar observasi aktivitas guru saat mengajar dalam menerapkan model pembelajaran discovery learning.

Berdasarkan pengamatan terhadap proses pembelajaran muatan IPA tema 4 menggunakan model pembelajaran $D L$ pada siswa kelas 5 SD Negeri Dukuh o1 diperoleh data aktivitas belajar siklus I. Aktivitas belajar meliputi aktivitas guru dan aktivitas siswa. Aktivitas guru adalah pelaksanaan sintaks model pembelajaran $D L$ oleh guru dalam pembelajaran muatan IPA tema 4 yang terdiri dari 20 indikator, pengamatan dengan rentang skor penilaian $1-5$ disajikan pada tabel 1 sebagai berikut:

TABEL 1

HASIL OBSERVASI AKTIVITAS GURU SIKLUS I

\begin{tabular}{|c|c|c|c|c|}
\hline \multirow[b]{2}{*}{ No } & \multirow{2}{*}{$\begin{array}{l}\text { Aspek Yang } \\
\text { Diamati }\end{array}$} & \multirow[b]{2}{*}{ Indikator } & \multicolumn{2}{|c|}{ Skor } \\
\hline & & & $\begin{array}{c}\text { Pertemuan } \\
1\end{array}$ & $\begin{array}{c}\text { Pertemuan } \\
2\end{array}$ \\
\hline 1 & $\begin{array}{l}\text { Kegiatan } \\
\text { Awal }\end{array}$ & $1-6$ & 20 & 24 \\
\hline 2 & $\begin{array}{l}\text { Kegiatan } \\
\text { Inti }\end{array}$ & $7-16$ & 28 & 38 \\
\hline 3 & $\begin{array}{l}\text { Kegiatan } \\
\text { Akhir }\end{array}$ & $17-20$ & 9 & 16 \\
\hline \multicolumn{3}{|c|}{ Total Skor } & 57 & 78 \\
\hline \multicolumn{3}{|c|}{ Kriteria } & Cukup Baik & Baik \\
\hline \multicolumn{3}{|c|}{ Rata-rata skor siklus 1} & \multicolumn{2}{|c|}{67,5} \\
\hline
\end{tabular}

Berdasarkan data tabel 1 dapat dilihat aktivitas guru pada pertemuan pertama dan kedua siklus I mengalami peningkatan.Pada pertemuan pertama memperoleh skor 57 dengan kriteria cukup meningkat menjadi 78 dengan kriteria tinggi pada pertemuan kedua. Sehingga diperoleh rata-rata skor aktivitas guru siklus I sebesar 67,5 .

Kemudian aktivitas siswa yang meliputi aktivitas siswa, yaitu kegiatan-kegiatan atau aktivitas-aktivitas yang dilakukan siswa selama pembelajaran.Observasi dilakukan menggunakan aspek pengamatan aktivitas yang terdiri dari 15 indikator, pengamatan dengan rentang skor penilaian $1-5$. Berdasarkan hasil observasi terhadap aktivitas individu siswa siklus I, diperoleh data hasil observasi yang disajikan dalam tabel 2 sebagai berikut:

TABEL 2

HASIL OBSERVASI AKTIVITAS SISWA SIKLUS I

\begin{tabular}{|l|l|r|r|r|}
\hline \multirow{2}{*}{ No } & \multirow{2}{*}{$\begin{array}{l}\text { Aspek Yang } \\
\text { Diamati }\end{array}$} & \multirow{2}{*}{$\begin{array}{c}\text { Indikat } \\
\text { or }\end{array}$} & & \multicolumn{2}{|c|}{$\begin{array}{c}\text { Skor } \\
\text { 1 }\end{array}$} & $\begin{array}{c}\text { Pertemuan } \\
\text { 2 }\end{array}$ \\
\hline 1 & $\begin{array}{l}\text { Kegiatan } \\
\text { Awal }\end{array}$ & $1-4$ & 9 & 15 \\
\hline 2 & $\begin{array}{l}\text { Kegiatan } \\
\text { Inti }\end{array}$ & $5-12$ & 21 & 27 \\
\hline 3 & $\begin{array}{l}\text { Kegiatan } \\
\text { Akhir }\end{array}$ & $13-15$ & 6 & 91 \\
\hline \multicolumn{2}{|l|}{ Total Skor } & \multicolumn{2}{|c|}{36} & 5 \\
\hline \multicolumn{2}{|l|}{ Kriteria } & \multicolumn{2}{|c|}{ Cukup Baik } & Baik \\
\hline \multicolumn{2}{|l|}{ Rata-rata skor siklus 1 } & \multicolumn{2}{|c|}{} \\
\hline
\end{tabular}

Berdasarkan data tabel 2, Pada pertemuan pertama diperoleh total skor sebesar 36 dengan kriteria cukup baik dan pada pertemuan ke dua sebesar 51 dengan kriteria baik. Sehingga rata-rata skor siklus 1 sebesar 43,5 .

Selanjutnya data hasil belajar muatan IPA tema 4 siklus I pada siswa kelas 5 SD Negeri Dukuh o1 diperoleh setelah dilaksanakannya tes evaluasi di akhir siklus I. Nilai rata-rata kelas 78,1 dengan nilai tertinggi 100, sedangkan nilai terendah 50. Ketuntasan belajar siklus I diperoleh data sebanyak 25 siswa atau 73,5\% dari keseluruhan siswa telah tuntas mencapai KKM (70), sedangkan yang belum tuntas sebanyak 9 siswa atau 26,5\% dari keseluruhan siswa. Artinya hasil belajar IPA siklus I belum memenuhi indikator hasil pencapaian $80 \%$ dari 34 siswa tuntas, maka perlu dilakukan tindak lanjut pada siklus II.

\section{Deskripsi Siklus II}

Perencanaan pada siklus II yang dilakukan oleh peneliti adalah memperbaiki kekurangan yang ada pada siklus I dan mempersiapkan alat penunjang lain yang perlu dilakukan pada siklus II. Pelaksanaan tindakan siklus II ini terdiri dari tiga pertemuan, yaitu pertemuan 1, 2 dan 3 yang berlangsung pada hari Selasa, Rabu dan Jumat tanggal 14, 15 dan 18 November 2017. Hal - hal yang dilakukan pada kegiatan Siklus II adalah Perencanaan antara lain :Rencana Pelaksanaan Pembelajaran (RPP) siklus II, lembar observasi atau pengamatan aktivitas siswa dalam proses pembelajaran, lembar observasi atau pengamatan aktivitas guru saat mengajar dengan menerapkan model pembelajaran discovery learning.

Berdasarkan pengamatan terhadap proses pembelajaran muatan IPA tema 4 menggunakan model pembelajaran discovery learning pada siswa kelas $5 \mathrm{SD}$ 
Negeri Dukuh o1 diperoleh data aktivitas belajar siklus II. Aktivitas belajar meliputi aktivitas guru dan aktivitas siswa. Aktivitas guru adalah pelaksanaan sintaks model pembelajaran discovery learning oleh guru dalam pembelajaran muatan IPA tema 4 yang terdiri dari 20 indikator, pengamatan dengan rentang skor penilaian 1 -5 disajikan pada tabel 3 sebagai berikut:

TABEL 3 .

HASIL OBSERVASI AKTIVITAS GURU SIKLUS II

\begin{tabular}{|l|l|l|l|l|}
\hline \multirow{2}{*}{ No } & $\begin{array}{c}\text { Aspek } \\
\text { Yang } \\
\text { Diamati }\end{array}$ & $\begin{array}{c}\text { Indikat } \\
\text { or }\end{array}$ & $\begin{array}{c}\text { Pertemuan } \\
\text { 1 }\end{array}$ & $\begin{array}{c}\text { Pertemuan } \\
\text { 2 }\end{array}$ \\
\hline 1 & $\begin{array}{l}\text { Kegiatan } \\
\text { Awal }\end{array}$ & $1-6$ & 24 & 30 \\
\hline 2 & $\begin{array}{l}\text { Kegiatan } \\
\text { Inti }\end{array}$ & $7-16$ & 42 & 48 \\
\hline 3 & $\begin{array}{l}\text { Kegiatan } \\
\text { Akhir }\end{array}$ & $17-20$ & 20 & 20 \\
\hline \multicolumn{2}{|l|}{ Total Skor } & 86 & 98 \\
\hline \multicolumn{2}{|l|}{ Kriteria } & Sangat Baik & Sangat Baik \\
\hline \multicolumn{2}{|l|}{ Rata-rata skor siklus II } & 92 \\
\hline
\end{tabular}

Sumber: hasil pengolahan data penelitian (2018)

Berdasarkan data tabel 3, dapat dilihat aktivitas guru pada pertemuan pertama dan kedua siklus II mengalami peningkatan. Pada pertemuan pertama memperoleh skor 86 dengan kriteria sangat baik meningkat menjadi 98 dengan kriteria sangat baik pada pertemuan kedua. Sehingga diperoleh rata-rata skor aktivitas guru siklus II sebesar 92. Berdasarkan hasil observasi terhadap aktivitas individu siswa siklus I, diperoleh data hasil observasi yang disajikan dalam tabel 4 sebagai berikut:

TABEL 4 .

HASIL OBSERVASI AKTIVITAS SISWA SIKLUS II

\begin{tabular}{|l|l|l|l|l|}
\hline \multirow{2}{*}{ No } & \multirow{2}{*}{$\begin{array}{c}\text { Aspek } \\
\text { Yang } \\
\text { Diamati }\end{array}$} & $\begin{array}{c}\text { Indikat } \\
\text { or }\end{array}$ & $\begin{array}{c}|c| \\
\text { Skor }\end{array}$ \\
\hline 1 & $\begin{array}{l}\text { Kegiatan } \\
\text { Awal }\end{array}$ & $1-4$ & 16 & 20 \\
\hline 2 & $\begin{array}{l}\text { Kegiatan } \\
\text { Inti }\end{array}$ & $5-12$ & 31 & 37 \\
\hline 3 & $\begin{array}{l}\text { Kegiatan } \\
\text { Akhir }\end{array}$ & $13-15$ & 11 & 14 \\
\hline \multicolumn{2}{|l|}{ Total Skor } & 58 & 71 \\
\hline \multicolumn{2}{|l|}{ Kriteria } & Cukup Baik & Sangat Baik \\
\hline \multicolumn{2}{|l|}{ Rata-rata skor siklus II } & 64,5 \\
\hline
\end{tabular}

Sumber: hasil pengolahan data penelitian (2018)

Berdasarkan data tabel 4 dapat dilihat terjadi peningkatan aktivitas individu siswa pada pertemuan pertama dan kedua siklus II. Pada pertemuan pertama diperoleh total skor pada pertemuan pertama sebesar 58 dengan kriteria cukup baik dan pada pertemuan ke dua sebesar 71 dengan kriteria sangat baik. Sehingga ratarata skor siklus II sebesar 64,5.

Selanjutnya data hasil belajar muatan IPA tema 4 siklus II pada siswa kelas 5 SD Negeri Dukuh 01 diperoleh setelah dilaksanakannya tes evaluasi di akhir siklus II. Nilai rata-rata kelas 88,7 dengan nilai tertinggi 100, sedangkan nilai terendah 76. Ketuntasan belajar siklus II diperoleh data sebanyak 34 siswa atau $100 \%$ telah tuntas mencapai KKM (70), Artinya hasil belajar IPA siklus II sudah memenuhi indikator hasil pencapaian $80 \%$ dari 34 siswa tuntas. Sehingga penerapan model pembelajaran discovery learning dalam pembelajaran muatan IPA pada kelas 5 SD Negeri Dukuh 01 dinyatakan berhasil meningkatkan proses dan hasil belajar.

\section{Analisis Komparatif \\ 1. Aktivitas Belajar}

Setelah dilakukan pengamatan terhadap proses pembelajaran muatan IPA tema 4 siklus I dan siklus II telah diperoleh data perbandingan hasil observasi aktivitas belajar yang disajikan dalam tabel 5 sebagai berikut:

Tabel 5

PERBANDINGAN ANALISIS RATA-RATA OBSERVASI SIKLUS I DAN SIKLUS II

\begin{tabular}{|c|c|c|c|c|c|c|}
\hline \multirow[b]{2}{*}{ Tindakan } & \multicolumn{2}{|c|}{ PraSiklus } & \multicolumn{2}{|c|}{ Siklus 1} & \multicolumn{2}{|c|}{ Siklus 2} \\
\hline & $\begin{array}{c}\text { Juml } \\
\text { ah } \\
\text { skor }\end{array}$ & $\%$ & $\begin{array}{c}\text { Juml } \\
\text { ah } \\
\text { skor }\end{array}$ & $\%$ & $\begin{array}{l}\text { Jumla } \\
\text { h skor }\end{array}$ & $\%$ \\
\hline $\begin{array}{l}\text { Aktivitas } \\
\text { guru }\end{array}$ & 34 & $34 \%$ & 86 & $\begin{array}{l}86 \\
\%\end{array}$ & 98 & $\begin{array}{l}98 \\
\%\end{array}$ \\
\hline $\begin{array}{l}\text { Aktivitas } \\
\text { siswa }\end{array}$ & 20 & $\begin{array}{l}26,7 \\
\%\end{array}$ & 61 & $\begin{array}{l}81,3 \\
\%\end{array}$ & 71 & $\begin{array}{l}94 \\
\%\end{array}$ \\
\hline
\end{tabular}

Sumber: hasil pengolahan data penelitian (2018)

Berdasarkan tabel 5 dapat diketahui bahwa terjadi peningkatan aktivitas guru dan aktivitas siswa dari siklus I, dan siklus II. Pada total skor aktivitas guru siklus I memperoleh skor 86 dengan perentase $86 \%$, dan pada siklus II meningkat menjadi 98 dengan persentase $98 \%$. Rata-rata skor aktivitas siswa juga mengalami peningkatan, pada siklus I rata-rata skor aktivitas siswa 61 dengan persentase $81,3 \%$, kemudian meningkat pada siklus II menjadi 71 dengan persentase $94 \%$.

\section{Hasil Belajar}

Hasil belajar diperoleh dari tes evaluasi yang dilakukan pada setiap akhir siklus. Dari Pra Siklus, siklus I, dan siklus II telah terjadi peningkatan nilai ratarata kelas dan ketuntasan belajar pada pembelajaran muatan IPA tema 4. Adapun data perbandingannya dasajikan dalam tabel 6 sebagai berikut:

\section{Tabel 6}

PERBANDINGAN KETUNTASAN DAN HASIL BELAJAR MUATAN IPA TEMA 4 PRA SIKLUS, SIKLUS I, SIKLUS II

\begin{tabular}{|c|c|c|c|c|c|c|c|}
\hline \multirow{2}{*}{$\begin{array}{c}\text { Ketuntas } \\
\text { an } \\
\text { Belajar }\end{array}$} & \multirow{2}{*}{$\begin{array}{c}\mathbf{K K} \\
\mathbf{M}\end{array}$} & \multicolumn{2}{|c|}{ Pra Siklus } & \multicolumn{2}{|c|}{ Siklus I } & \multicolumn{2}{|c|}{ Siklus II } \\
\hline & & Jml & $\%$ & Jml & $\%$ & Jml & $\%$ \\
\hline Tuntas & $\geq 70$ & 13 & 38,24 & 25 & 73,5 & 34 & 100 \\
\hline Belum & $\leq 70$ & 21 & 61,7 & 9 & 26,5 & o & o \\
\hline
\end{tabular}




\begin{tabular}{|l|l|l|l|l|l|l|}
\hline Tuntas & & & & & & \\
\hline Jumlah & 34 & 100 & 34 & 100 & 34 & 100 \\
\hline Nilai Rata-rata & 63,5 & & 78,1 & 88,7 \\
\hline
\end{tabular}

Sumber: hasil pengolahan data penelitian (2018)

Berdasarkan tabel 6 tentang perbandingan ketuntasan belajar muatan IPA, dapat diketahui bahwa terdapat peningkatan hasil belajar dari Pra Siklus, siklus I, dan siklus II. Ketuntasan belajar siswa yang diperoleh dari Pra Siklus siswa yang mencapai kriteria ketuntasan minimal $(\mathrm{KKM}=70)$ sejumlah 13 siswa atau $38,24 \%$, yang belum mencapai KKM sejumlah 21 siswa atau $61,76 \%$ dengan rata-rata hasil belajar muatan IPA 63,5. Ketuntasan belajar pada siklus I siswa yang mencapai KKM sejumlah 25 siswa atau $73,5 \%$, yang belum mencapai KKM sejumlah 9 siswa atau 26,5\% dengan rata-rata hasil belajar IPA 78,1. Sedangkan katuntasan siswa pada siklus II siswa yang mencapai KKM sejumlah 34 siswa atau 100\%, yang belum mencapai KKM sejumlah o siswa atau tidak ada dengan rata-rata hasil belajar IPA 88,7. Dari hasil belajar IPA dan ketuntasan belajar siswa siklus II dapat diketahui bahwa indikator keberhasilan tindakan penelitian menggunakan model pembelajaran discovery learning yang telah ditentukan oleh peneliti sudah tercapai (ketuntasan belajar siswa $\geq$ $80 \%)$.

\section{Pembahasan}

Rendahnya aktivitas belajar muatan IPA diketahui berdasarkan hasil observasi pembelajaran muatan IPA prasiklus di kelas 5 SD Negeri Dukuh 01. Hasil aktivitas guru pra siklus yang memperoleh total skor 34 dengan persentase $34 \%$, kemudian aktivitas siswa pada prasiklus memperoleh total skor 20 dengan persentase $26,7 \%$. ternyata dapat berpengaruh terhadap hasil belajar muatan IPA di kelas 5 SD Negeri Dukuh o1 yang dibuktikan berdasarkan tingkat ketuntasan hasil belajar prasiklus, bahwa siswa yang tuntas atau telah mencapai KKM (70) hanya 13 siswa atau 38,24\% dari jumlah keseluruhan siswa, sedangkan yang belum mencapai KKM ada 21 siswa atau 61,76\% dari jumlah keseluruhan siswa. Berdasarkan kondisi yang demikian maka peneliti merasa diperlukan adanya tindakan perbaikan pembelajaran untuk meningkatkan hasil belajar muatan IPA tema 4 siswa kelas 5 SD Negeri Dukuh 01 dengan menerapkan model pembelajaran discovery learning.

Setelah pembelajaran muatan IPA tema 4 dengan menerapkan model pembelajaran discovery learning dilaksanakan secara keseluruhan pada siklus I dan siklus II. Siswa menjadi lebih berpartisipasi aktif dalam proses pembelajaran. Terbukti dari data hasil observasi aktivitas siswa yang telah dipaparkan pada tabel 4 . Meningkatnya aktivitas belajar siswa diikuti dengan meningkatnya hasil belajar muatan IPA tema 4 yang terlihat dari peningkatan nilai rata-rata kelas siklus I sebesar 78,1 dengan ketuntasan mencapai 73,5\%. Namun pencapaian tersebut belum mencapai indikator keberhasilan yang ditentukan peneliti yaitu sebesar 80\%, oleh karena itu diadakan reflekasi sebagai perbaikan pada siklus II. Pada siklus II diperoleh nilai rata-rata kelas meningkat menjadi 88,7 dengan pencapaian ketuntasan belajar mencapai 100\% tuntas. Berdasarkan pencapaian ketuntasan pada siklus II, maka hasil pelaksanaan tindakan pada siklus II telah mencapai indicator ketuntasan yang ditetapkan peneliti sebesar $80 \%$ siswa tuntas.

Model discovery learning membuat siswa dapat belajar dalam suasana yang menyenangkan, dan merasa memiliki kemampuan untuk menemukan sesuatu yang baru, mengurangi perasaan takut dan tegang yang dirasakan oleh siswa saat mengikuti proses pembelajaran. Pembelajaran dengan menggunakan model pembelajaran discovery learning juga menjadikan siswa dapat berinteraksi dan bekerja sama dengan baik dengan siswa yang lain. Selain itu guru juga menanamkan pada peserta didik pentingnya pengamatan empiris dalam menguji suatu pernyataan ilmiah (hipotesis). Hipotesis ini dapat berasal dari pengamatan terhadap kejadian sehari-hari yang memerlukan pembuktian secara ilmiah, latihan berpikir kuantitatif yang mendukung kegiatan belajar muatan IPA, yaitu sebagai penerapan muatan IPA pada masalahmasalah nyata yang berkaitan dengan peristiwa alam, hal ini dimaksudkan untuk menambah semangat siswa dalam mengikuti pembelajaran.

Dengan pelaksanaan tindakan pembelajaran pada siklus I dan siklus II dengan menerapkan model pembelajaran discovery learning siswa bisa merespon pertanyaan dari guru, siswa bisa mengenal masalah, siswa bisa memecahkan masalah, siswa bisa menyelidiki masalah sendiri, siswa bisa berfikir intuisi dan merumuskan hipotesis sendiri, siswa bisa mengembangkan bakat dan kecakapan individu, siswa bisa berfikir dan menggunakan kemampuan untuk menemukan hasil akhir sehingga siswa menjadi lebih aktif dan guru bisa melakukan inovasi dalam pembelajaran sehingga dapat meningkatkan aktivitas dan hasil belajar muatan IPA khususnya tema 4 sehat itu penting. Berdasarkan uraian penelitian yang telah disajikan, maka penerapan model pembelajaran $D L$ dalam pembelajaran muatan IPA pada siswa kelas 5 SD Negeri Dukuh 01 Kecamatan Sidomukti Kota Salatiga Tahun Pelajaran 2017/2018 terbukti bahwa penerapan model pembelajaran discovery learning dapat meningkatkan hasil belajar siswa.

\section{SIMPULAN DAN SARAN}

Setelah menerapkan model pembelajaran discovery learning dengan langkah-langkah meliputi tahap Stimulation (stimulasi/pemberian rangsangan), Problem statement (pernyataan/ identifikasi masalah), Data collection (pengumpulan data), Data processing (pengolahan data), Verification (pentahkikan/pembuktian), Generalization (menarik 
kesimpulan/generalisasi) pada muatan IPA tema 4 bahwa penerapan model pembelajaran discovery learning dapat meningkatkan proses dan hasil belajar muatan IPA tema 4 siswa kelas 5 SD Negeri Dukuh 01 tahun pelajaran 2017/2018.Diketahui hasil observasi aktivitas guru siklus I rata-rata aktivitas guru $86 \%$, pada siklus II rata-rata aktivitas guru meningkat menjadi 98\%.Peningkatan juga terlihat pada hasil observasi aktivitas siswa. Hasil observasi siswa siklus I rata-rata aktivitas siswa $81,3 \%$, pada siklus II rata-rata aktivitas siswa meningkat menjadi 94\%. Seiring dengan hasil aktivitas guru dan aktivitas siswa yang meningkat maka berpengaruh terhadap hasil belajar muatan IPA tema 4 siswa yang juga turut meningkat. Hal ini dapat dibuktikan dari perolehan nilai siswa kondisi awal hingga pada pelaksanaan tiap siklusnya yang mengalami peningkatan. Pada kondisi awal mula-mula nilai ratarata hasil tes muatan IPA tema 4 siswa kelas 5 SDN Dukuh 01 adalah 63,5 dengan persentase ketuntasan siswa sebesar $38,24 \%$. Kemudian setelah pelaksanaan tindakan siklus I dengan menerapkan model pembelajaran discovery learning hasil belajar muatan IPA tema 4 mengalami peningkatan dari perolehan kondisi awal sebelumnya, nilai rata-rata yang diperoleh siswa setelah pelaksanaan tindakan siklus I menjadi 78,1 dengan besarnya persentase ketuntasan $73,5 \%$, kemudian setelah pelaksanaan tindakan pembelajaran pada siklus II nilai rata-rata hasil evaluasi muatan IPA tema 4 meningkat menjadi 88,7 dengan persentase ketuntasan 100\%. Sehingga penerapan model discovery learning terbukti dapat meningkatkan hasil belajar muatan IPA tema 4 siswa kelas 5 SD Negeri Dukuh 01 Tahun Pelajaran 2017/2018.

\section{Saran}

1. Bagi Guru: Guru sebagai kunci di dalam perencanaan sebuah pembelajaran hendaknya lebih kreatif dalam memberikan motivasi kepada siswa agar lebih aktif mengikuti pembelajaran dan memberikan sikap positif atau penghargaan dari hasil aktivitas belajar siswa agar dapat memotivasi keaktifan belajar siswa.

2. Bagi Siswa: Siswa sebagai subjek utama dalam proses pembelajaran hendaknya dapat memahami konsep materi pelajaran serta diharapkan terlibat aktif dalam proses pembelajaran guna memperoleh pengetahuan dan pemahaman, sehingga hasil belajar dapat meningkat, khususnya hasil belajar muatan IPA dan sebaiknya siswa mempunyai tim sebaya untuk belajar secara berkelompok dan saling bertukar pengetahuan sehingga dapat meningkatkan hasil belajar siswa.

\section{UCAPAN TERIMA KASIH}

Dengan ini penulis mengucapkan terimakasih kepada Bapak Drs. Nyoto Harjono, M.Pd., Bapak Gamaliel Septian Airlanda, M.Pd. Guru kelas 5 Bapak Ahmad
Muklisin, A.Ma dan siswa kelas 5 SD Negeri Dukuh 01 yang telah membantu kami sehingga penulis dapat menyelesaikan penelitian ini.

\section{DAFTAR RUJUKAN}

[1] Anitah, S. (2009). Teknologi Pembelajaran. Surakarta: Yuma Pustaka.

[2] Chatib, M. (2012). Orang tuanya Manusia: Melejitkan Potensi dan Kecerdasan Dengan Menghargai Fitrah Setiap Anak. Bandung: Kaifa.

[3] Depdiknas. 2005. Landasan Teori dalam Pengembangan Metode Pengajaran. Materi Pelatihan Terintegrasi Ilmu Pengetahuan Alam. Jakarta: Depdik-nas Dirjen Pendasmen Direktorat Pend. Lanjutan Pertama.

[4] Hosnan. (2014). Pendekatan Saintifik Dan Kontekstual Dalam Pembelajaran Abad 21. Jakarta: Ghalia Pustaka.

[5] Kemendikbud. 2013. Materi Pelatihan Guru, Implementasi Kurikulum 2013.Jakarta: Kementerian Pendidikan dan Kebudayaan.

[6] Kemendikbud, 2016. Panduan Teknis Pembelajaran Dan Penilaian Di Sekolah Dasar. Jakarta: Direktorat Pembinaan Sekolah Dasar.

[7] Madjid, A. (2014). Pembelajaran Tematik-Terpadu. Bandung: Remaja Rosdakarya.

[8] Oemar Hamalik. 2006. Proses Belajar Mengajar. Bandung. Bumi Aksara

[9] Permendikbud RI Nomor 66 Tahun 2013 tentang Kerangka Dasar dan Struktur Kurikulum Sekolah Dasar / Madrasah Ibtidaiyah

[10] Rumidani, N. M., Marhaeni, A. I., \& Tika, I. N. (2014). Implementasi Pembelajaran Tematik Berbasis Lingkungan Untuk Meningkatkan Motivasi Dan Hasil Belajar Calistung Siswa Sekolah Dasar. e-Journal Program Pascasarjana Universitas Pendidikan Ganesha , 4.

[11] Saifuddin. (2014). Pengelolaan Pembelajaran Teoretis Dan Praktis. Yogyakarta: Deepublish.

[12] Suparno, P. (2012). Filsafat Konstruktivisme Dalam Pendidikan. Yogyakarta: Kanisius.

[13] Wicaksono,dkk. (2015). Teori Pembelajaran Bahasa (Suatu Catatan Singkat). Yogyakarta: Garudhawaca.

\section{PROFIL PENULIS UTAMA}

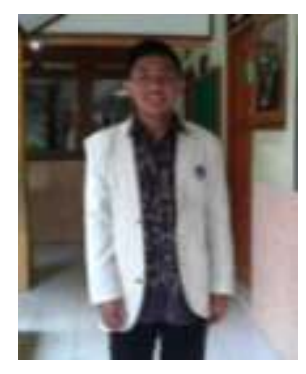

Penulis bernama lengkap "Rizki Sofyan Rizal". Lahir di Desa Gondangslamet Kecamatan Ampel Kabupaten Boyolali Provinsi Jawa Tengah pada tanggal 13 Februari 1996 dari pasangan Mugiyanto dan Sri Winarsih. Penulis adalah anak kedua dari 2 bersaudara. Pendidikan sekolah dasar dimulai dari SDN Gondangslamet o1 Kecamatan Ampel pada tahun 2002 - 2008. Setelah itu melanjutkan pendidikan sekolah menengah ke SMPN 1 Ampel pada tahun 2008 - 2011 dan terakhir di SMAN 3 Boyolali pada tahun 2011 - 2014. Kemudian penulis melanjutkan studi ke perguruan tinggi di Program Studi Pendidikan Guru Sekolah Dasar FKIP UKSW pada tahun 2014. Kritik, saran, maupun hal-hal yang berkaitan dengan kelanjutan atau pengembangan dari hasil penelitian ini bisa dikirim ke email penulis di : 292014058@student.uksw.edu 